\title{
Circular patterns of waste prevention and recovery
}

\author{
Patrizia Ghisellini ${ }^{1}$, Remo Santagata ${ }^{1}$, Amalia Zucaro $^{2,}{ }^{*}$ and Sergio Ulgiati ${ }^{1}$ \\ ${ }^{1}$ Parthenope University of Naples, Department of Sciences and Technologies, 80143 Napoli, Italy \\ ${ }^{2}$ ENEA, Laboratory Resources Valorisation, Research Centre of Portici, Portici, 80055 Napoli, Italy
}

\begin{abstract}
The growth of modern societies with their scientific, economic and social achievements was made possible by the cheap availability of fossil fuels. Side effects of fossil energy resources were the development of unsustainable production and consumption patterns, the degradation of natural capital, and the release of airborne, waterborne and solid waste. Consumption and environmental loading are not only related to fuels, but also to other material resources, such as minerals in general and rare earths in particular. The increasing shortage of crucial resources affects and constrains important economic sectors (e.g., electronic sectors, renewable energies, food production), thus placing a limit on further development and wellbeing. Concepts of sustainable economies and communities, with focus on the social dimension of development and also on the ecological and economic aspects at the same time, are gaining the attention of policy makers, managers, and investors, as well as local stakeholders (organisations, small and medium enterprises, individual citizens) and encouraging new development and business models globally referred to as the "circular economy". The circular economy (CE) is a production and consumption system that is restorative by intention and design. Although there has been a relative decoupling of economic growth from resource use in recent decades, the gains made so far have been eaten up by a combination of economic growth and the rebound effect. There are two questions: (i) why has it been so hard to move from theory (most often from rhetoric) to practice and implementation, and (ii) how is it possible to promote an innovative and effective CE strategy in urban systems where $60 \%$ of world population is concentrated. This shift (design, networking, organisation, implementation, community planning) and related monitoring tools constitute the skeleton of the transition that needs to occur within both urban systems and economies. The point we make is that a society without waste is not only desirable, but also possible and necessary. We cannot wait longer and we cannot just accept small adjustments, increased end-of-pipe technologies and the usual interplay of promises and conflicts. The time for a massive and successful effort towards a radical change of lifestyles and production/consumption patterns is now, where the term "waste" itself is considered a symptom of societal illness, an indicator of immature economies, poor science and old-fashioned technology.
\end{abstract}

\section{Introduction}

The global transition to the circular economy has just started but the effects of the transition are limited so far [1]. The linear model of production and consumption thus still dominates in the global economy [2].

One of the most evident effects of the unsustainability of the linear model [3] is the generation of an enormous amount of waste worldwide [4]. Indeed, the concept of waste is something new in natural cycles, where normally the waste discarded becomes resources for other users [2]. Conversely, human activities are generating waste at a pace higher than the capacity of the natural environment or production processes can reuse them [5].

Recently the accumulation of mismanaged plastic waste (MPW) has been of particular concern regarding very fragile natural habitats such as oceans [6] where every year millions of tonnes of plastic waste are dumped (about 8 million) [7]. This emphasises how strongly the local and global scales are intertwined and the importance of taking responsibility at the local level while thinking at the global level [8, 9]. Most MPW is actually transported via larger watersheds such as rivers to the oceans [6].

Post-consumption waste is only the tip of an iceberg that can be renamed the "wasteberg", compared to the amount of waste coming from upstream manufacturing activities [10].

This highlights the need to redefine the approach to waste management by taking an integrated and preventive circular perspective [4], taking into account upstream and downstream sources of generation for the final goal of slowing the pace of production and consumption activities and closing resource flows.

In this study we evaluate waste generation and management in Italy, within the broader framework of

\footnotetext{
Corresponding author: amalia.zucaro@enea.it
} 
the trends and practice of waste management performed worldwide.

\section{The transition from a linear, wasteful, fossil-based society to resource efficiency and circular economy concepts}

The growth of modern societies with their important scientific, economic and social achievements was made possible by the cheap availability of fossil fuels in the last two centuries. Unfortunately, one of the consequences of using fossil energy resources was the development of unsustainable production and consumption patterns based on large energy use, the intensive degradation of natural capital, and the large generation of airborne, waterborne and solid waste, most of which is barely degradable. The load placed on natural capital (clean air, fresh water, biodiversity, topsoil, etc.) is the "new scarcity" problem faced by modern societies, and adds to the commonly acknowledged scarcity of energy, minerals and other crucial commodities [11, 12]. Consumption and environmental loading are related not only to fuels, but also to other material resources, such as minerals in general and rare earths in particular. The increasing shortage of crucial resources affects and constrains important economic sectors (e.g., the electronic sectors, renewable energies, and food production), thus placing a limit on further development and wellbeing. Concepts of sustainable economies and communities, with a focus on the social dimension of development and the ecological and economic aspects at the same time, are gaining the attention of policy makers, managers, investors and local stakeholders (organisations, small and medium enterprises, individual citizens) in new development and business models globally referred to as the "circular economy" $[13,14]$. The much-needed transition from non-renewable to renewable energy and material resources would be a significant step forwards towards a more sustainable society and urban living: the circular economy has the potential to become an important framework within which such a transition is likely to occur [15].

The need to establish new patterns of socio-economic development has played, in recent years, a priority role in local government agendas worldwide, with the main objective to safeguard natural capital and environmental services, which are also perceived as a real asset for the benefit of future generations. Special attention has recently been paid to sustainable urban communities by a large number of scholars, agencies and NGOs in order to develop the concept further and make demonstrated good practices available for comparison and implementation $[16,17,18]$. The concept of sustainability plays a more important role than simply limiting carbon emissions, or implementing solar electricity, or even increasing waste recycling. It includes all social, economic and environmental aspects of urban communities: quality of life, wealth, jobs, community services, and the sound relationship between production and consumption activities and the environment. In this context, it is of paramount importance to note that most often "green is not enough", in that an apparently sustainable technology outside the appropriate context or network may not be a solution, and may instead add new problems to the existing burden. Innovative patterns must be properly assessed within the constraints and needs of a local community under the diverse perceptions of stakeholders $[19,20]$. Suggestions for future steps towards production patterns that emulate natural processes have been developed by Pauli $[21,22]$ as a so-called "Blue Economy" approach.

As commonly noted, the purpose of the Circular Economy (CE) is to provide a better alternative to the dominant model of economic development, the so-called "take, make and dispose" model [23]. Its negative effects are threatening the stability of economies and the integrity of natural ecosystems that are essential for humanity's survival [24-32]. Many different studies have been published about the content and development of CE worldwide [17, 33-38]. A large number of these studies concern the implementation of CE in China. China was the first big economy in the world to develop circular policies, making CE a fundamental pillar of its national economic strategy $[39,40]$. This country seems strongly attracted by and committed to CE because of the huge environmental, human health and social problems posed by its very rapid and continuous pattern of economic development [41-44]. The circular economy is seen in China as a new development model that is expected to lead to more sustainable development and a harmonious society [45-47].

The CE is a production and consumption system that is restorative by intention and design [15, 48]. Rather than discarding products before their value is fully utilised, we should use and re-use them. Presently only a few percentage points of the original product's value are recovered after use. While there has been a relative decoupling of economic growth from resource use in recent decades, the gains made so far have been rapidly eaten up by a combination of economic growth and the so-called rebound effect (or Jevons paradox), where the resources freed up by increased efficiency are used up very quickly through increased consumption. This is where the CE comes into play as a powerful concept. The European Commission took important initiatives in the area of resource efficiency in 2011-2014, with a first Circular Economy Package [24, 25] further refined to become an ambitious Circular Economy Action Plan [49, 50].

\section{Waste Management worldwide}

A recent report by The World Bank (2018) [51] demonstrated that at the global level about 2.01 billion tonnes of municipal solid waste (MSW) were produced in 2016 (sum of all values in Figure 1), and the average amount of waste generated per person per day was 0.74 kilogram. MSW generation per capita is strongly correlated with national income. In high-income 
countries, MSW generation rates are stabilising or slightly decreasing, possibly reflecting the probable decoupling of waste from economic growth [52]. High income countries, despite being $16 \%$ of the world's population, however, generate about $34 \%$ of the world's annual MSW, equal to 683 million tonnes [51].

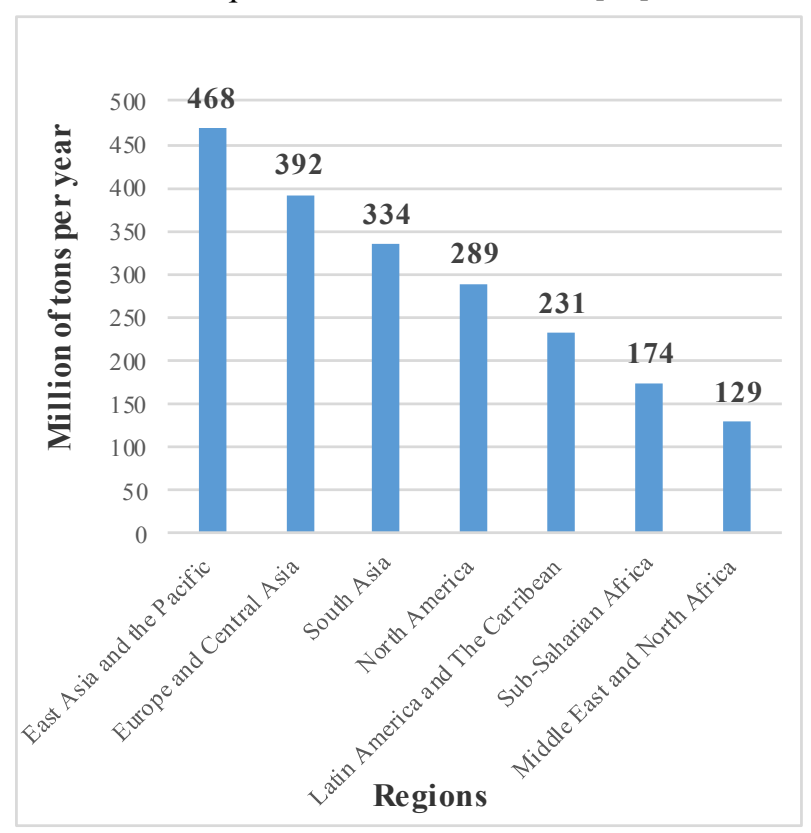

Fig. 1. Waste generation across regions in 2016. Source: The World Bank, 2018 [51].

Waste management (WM) continues to improve at the global level, through the observable and increasing trend of recycling and composting [51]. Recycling currently accounts for only $13.5 \%$ of the global disposal of waste, however, as shown in Figure 2, where it can also be seen that a large share is disposed of in landfill (controlled landfill, landfill (unspecified) and sanitary landfill) and open dumps (33\%). Open dumps are almost the only option in lower income countries, providing 93\% of the total treatment in those countries. In uppermiddle-income countries, slightly more than the half of waste is landfilled (54\%). This share further reduces to $39 \%$ in high-income countries, where a large share is also recycled $(36 \%)$ and incinerated (22\%). The latter is mainly practiced in high-capacity, high-income, and land-constrained countries [51] such as Japan [53, 54].

Data from the World Bank [51] also demonstrates that there is a change in waste composition ${ }^{1}$ in lowincome countries, due to the modification of consumption patterns, that in turn depend on changes in income levels. The organic waste share of total waste composition has reduced over time, reaching $56 \%$. The organic fraction in low income countries has a greater share in waste composition than in high income countries and ranges between $20-40 \%$. On the other side, the share of recyclable fractions - such as plastic, paper, cardboard, metal, and glass - accounts for $51 \%$ of total waste composition in high income countries [51].

\footnotetext{
1 Waste composition refers to the components of the waste stream as a percentage of the total mass generated.
}

The World Bank (2018) report [51] evaluates global waste generation and management, grouping countries into areas other than the conventional continents, on the basis of factors such as income and economic structure levels. The international literature, also provides data at the individual country level in a given area (e.g. Ghana), or in some cases for continents such as Africa $[55,56]$.

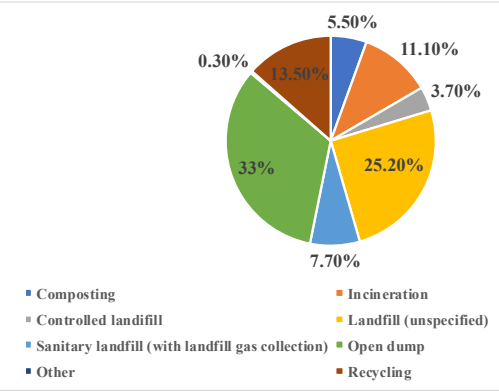

Fig. 2. Share of the different waste management options in the global treatment and disposal of waste (\%).

\subsection{Sub-Saharan Africa, Middle East and North Africa}

Figure 1 shows that the amount of waste generated in these areas is low compared to the total MSW generated annually at the world level [51]. In particular, for African countries, several authors $[55,56]$ demonstrate how waste management in Africa is a growing environmental and health problem, given the increase in waste generation and the inadequate MSW management (MSWM) systems. The latter is unable to provide a service proportional to the needs, due to institutional, technical and financial barriers at national and local government levels $[55,56]$. Technical barriers involve provision of the service, collection, treatment, transportation, storage, and final disposal, as well as the insufficient presence of infrastructure and land use planning [55].

\subsection{Sub-Saharan Africa, Middle East and North Africa}

India, China, Japan and Australia, among others, are included in this area. However, these countries are highly diversified in terms of income levels, waste generation and management practices. MSWM is dominated by landfilling in India and China (e.g., in China $60 \%$ of MSW is still disposed of in landfills) [57], although both countries are investing in MSW management options other than landfill [58]. China's programme is most closely related to the circular economy transition [40].

The ASEAN countries ${ }^{2}$ are included in this area, of which Indonesia, with 64 million tonnes/year, produces the highest amount of MSW, followed by Thailand (26.77 million/tonnes/year) [59]. In China and India, the

2 The association of Southeast Asian Nations includes Indonesia, Malaysia, The Philippines, Singapore, Thailand, Brunei, Darussalam, Cambodia, Laos, Myanmar and Vietnam. 
most commonly adopted practices for waste management are open dumping and open burning, even if other practices such as composting and the anaerobic digestion of organic waste, as well as the recovery of plastic, metals and paper, are developing. Singapore is reported to have a well-structured municipal MSWM, even if the most commonly practiced management option for waste is incineration [59].

\subsection{Europe and Central Asia}

European Union member states are included in this area, together with the Russia Federation. The data available from Eurostat for EU countries shows that in 2017 the EU (28 countries) generated 248,653,000 tons of $\mathrm{MSW}^{3}$ which is an average per capita amount of $486 \mathrm{~kg}$ [61]. This was slightly higher than the average of $470 \mathrm{~kg} / \mathrm{per}$ capita in 1995 [62].

MSW management in European countries is now more focused on prevention and recycling compared to the past decades. Over the period 1995-2017 the amount of MSW landfilled decreased by $60 \%$ while recycling increased by $196 \%$ [63]. Landfilling is still widely practiced in more than the $50 \%$ of EU countries, however, as shown in Figure 3.

The scaling up of the waste hierarchy towards waste prevention, preparing for reuse, recycling, recovery and disposal is essential for better waste valorisation, as well as reducing the pressures on the environment, creating jobs and making the transition to the $\mathrm{CE}$ a reality in $\mathrm{EU}$ $[64,65]$.

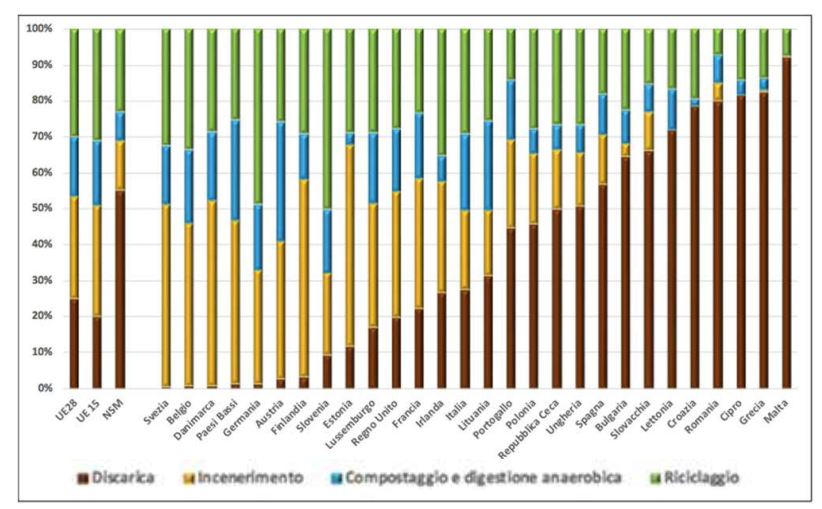

Fig. 3. Waste treatment methods in Europe, 2016 (ISPRA, 2018 [66]; based on Eurostat data5). Translation of Italian captions: Discarica $=$ landfilling; Incenerimento $=$ waste to energy; Compostaggio e digestione anaerobica $=$ composting and anaerobic digestion; Riciclaggio $=$ recycling).

\subsection{North America}

The Environmental Protection Agency (2018) [67] reports that citizens of the USA generated an average of

\footnotetext{
${ }^{3}$ Municipal waste consists of waste collected by or on behalf of municipal authorities and disposed of through waste management systems. Municipal waste consists mainly of waste generated by households, although it also includes similar waste from sources such as shops, offices and public institutions [60].
}

$741.7 \mathrm{~kg}$ per capita of $\mathrm{MSW}^{4}$ in 2015 , when the total MSW produced in the USA was 262 million tons.

The WM approach in the US evolved over time from one centred on landfilling towards an integrated and holistic approach that considers waste as a resource. Waste is managed according to a hierarchy that places waste reduction at the source at the top of the preferred strategies and landfilling as the less preferred option [68]. Since 1980, the recycling and composting of MSW increased, reaching a recycling and composting rate equal to $34.7 \%$ in 2015 . This contributed to reducing the share of landfilled MSW, which was about $52.5 \%$ of the total MSW generated in 2015. Of other treatment options, $12.8 \%$ are combusted for energy recovery, and $34.7 \%$ of MSW are recycled $(25.8 \%)$ and composted $(8.9 \%)$.

\subsection{Latin America and Caribbean (LAC)}

Similar to other emerging economies, this group of countries is also experiencing increasing rates of waste generation, particularly in cities where the population has dramatically increased over time. In 2016, this area generated 231 million tons of MSW [51]. This is reported to be mainly disposed of in landfills, and recycling as a treatment option comprises a very low share $(2 \%)$ of the total MSWM system, because this area has not implemented a sorting collection system [69]. Lots of potentially valuable materials that could be recycled end up in landfills and dumps, leaving space for informal sorting activities by the poorer fractions of local populations.

The literature also notes that uncontrolled open-air dumps are used by a large fraction of the population in some countries of the region (such as Belize) and operational and environmental problems are demonstrated as due to failures in the implemented landfills (such as in Mexico and Columbia) [69].

\subsection{The "wasteberg" in Italy}

The "wasteberg" concept found quick and very broad acceptance worldwide, in support of the idea of the enormous amount of hidden waste behind the comparatively small amount of municipal waste that we see every day. Some estimates suggest that hidden waste (the bottom of the wasteberg) makes up about 71 tons per ton of municipal waste [70]. Whether the "71 times" estimate is correct or not, even 30,15 or 10 times would be an unsustainable amount, spread all over the planet, degrading the landscape and making life impossible or very hard in many areas of the planet.

Even without going into the details of such an estimate, we may note that the amount of municipal

\footnotetext{
${ }^{4}$ MSW consists of various material fractions that Americans commonly throw away after being used. These include packaging, food waste, grass clippings, sofas, tyres, computers and refrigerators, the latter most often categorized as WEEE (Waste Electric and Electronic Equipment). MSW does not include industrial, hazardous, or construction waste [67].
} 
waste in Italy in 2016 was about 30 million tons, compared with about 135 million tons of non-municipal waste (all the other kinds of waste material are associated with the industrial, agricultural, transport sectors, to quote only the largest) [66]. Of these, construction and demolition waste amounted to 55 million tons, and waste associated with waste collection, treatment and disposal (waste generation to dispose of the waste already generated!) was as much as 35 million tons. Other categories of waste are collected outside the usual daily garbage collection from households and restaurants. Such an amount, 4.5 times the amount of municipal waste, does not include all the abiotic, biotic, eroded soil, water and atmospheric releases that are indirectly associated with all mining and production activities worldwide, over the entire LCA (Life Cycle Assessment) supply chain. Therefore, municipal waste is just the tip of the Italian wasteberg, and is estimated as much smaller than the amount of degraded and polluted water, land and rocks, soil, and emissions released - not necessarily in Italy - in support of the Italian economy. It is surprising that most environmental conflicts occur around the small amount of waste we can see daily (the location of a landfill, plans for an incinerator/waste-toenergy plant, MBT, mechanical biological treatment plants, etc.), while we are most often unaware of the size of the bottom of the wasteberg. There is no need to say that the transition to zero-waste, or at least reducedwaste economies, is urgent, and can no longer be delayed.

\section{Progress is slow. Need to move from rhetoric to action}

More than forty years have passed since the launch of "Limits to Growth". Its key message was that a combination of resource depletion and pollution, if untackled, would ultimately - within the next hundred years - take the global economy down. The message was that Planet Earth is physically limited and relatively small compared to rapidly increasing human activities. Few reports have become so controversial and, not least among economists, so heavily criticised. The main criticism centred on the fact that the report was based primarily on higher consumption trends, while not taking technological development, substitution and price adjustments sufficiently into account. The human ecological footprint has continued to increase, anyway, no matter how we like to measure it, due to the growing population, growing welfare expectations and achievements, improved exploitation technologies, increased demand for construction minerals, biomass for food and feed, and fossil energy carriers. These three material groups account for $80 \%$ of total global material extraction. Governments and businesses now seem to understand that the basically linear systems of resource use expose both societies and businesses to serious risks. Resource constraints and the increasing volumes of waste and pollution are likely to pose increasing threats to welfare and wellbeing and, from a business point of view, to competitiveness, profits and business continuity.
Industrial Symbiosis in the Danish town of Kalundborg $^{5}$, has been a reference case for eco-industrial parks development for decades [71, 72]. In this town, the appropriate management of an oil refinery/coal-fired power plant and urban waste allowed huge savings of energy, water ( 3 million $\mathrm{m} 3 / \mathrm{yr}$ ), and fuel oil $(20,000$ $\mathrm{t} / \mathrm{yr}$ ), a large decrease of SO2 emissions, the recovery of ashes for nickel and vanadium extraction, and for cement production, the delivery of hot water to smaller users and to the city district heating system, among other benefits. The Kalundborg Eco-Industrial Park was not initially designed as such, however, but gradually evolved over time when local players discovered that energy and waste exchanges resulted in economic benefits for all parties involved. If preventive planning comes into play, much faster and more ambitious results can be expected.

The Ellen MacArthur Foundation in its first report Towards a Circular Economy I) [13] mainly focused on the business aspects of CE: "A circular economy is an industrial system that is restorative by intention and design. In a circular economy, products are designed for ease of reuse, disassembly and remanufacturing - or recycling - with the understanding that it is the reuse of vast amounts of material reclaimed from end-of-life products, rather than the extraction of new resources, that is the foundation of economic growth. Moreover, the circular economy shifts towards the use of renewable energy, eliminates the use of toxic chemicals, which impair reuse, and aims for the elimination of waste through the superior and innovative design of materials, products, systems, and, within this, business models." A second study by the foundation, Towards the Circular Economy II [73] suggests that the adoption of CE could be worth as much as USD 700 billion in consumer material savings alone. The study also highlights the added benefits in terms of land productivity and potential job creation.

There are two questions: (i) why has it been so hard to move from theory to practice? and (ii) how can an innovative and effective CE strategy be promoted in urban systems where $60 \%$ of the world population is concentrated? Special attention has been recently paid to sustainable urban communities by a large number of scholars, agencies and NGOs in order to further develop the CE concept at the urban level, and make good practices available for comparison and implementation [15-17]. These studies and proposals for urban CE favoured the introduction of institutional policies in Europe and worldwide [74, 75], although they would need practical implementation and clear roadmaps. Given urban population trends, the transition to more sustainable living should start from cities, or else it is unlikely to happen. The real issue is that most theoretical achievements have not yet been translated into broad practical CE planning and implementation.

If the Circular Economy (CE) is to become the next framework and business model, a breakthrough innovation is needed that addresses the shift from a linear production pattern (where waste and pollution are

\footnotetext{
5 http://www.symbiosis.dk/
} 
the rule) to complex networks (where waste from a process is the raw input for another process and emissions are minimised). Such complex patterns also require complex and flexible technologies and complex and comprehensive evaluation tools [76, 77], to understand and properly address network, substrates, technology and methodological complexities, and thus develop a theoretical integrated framework and operational model.

\section{A circular economy within urban systems}

The development of a circular economy in cities, provinces or regions involves the integration of four subsystems: industry, infrastructure, the cultural framework and the social and public service system [23, 37]. At the city or regional (provincial) levels, pollution prevention becomes of paramount importance; this is characterised by material and energy circulation and has, as its ultimate objective, more sustainable social, economic, and environmental development, including optimum energy and resource use and the reduction of waste discharge [35].

In urban centres the $\mathrm{CE}$ transition may require the redesign of support infrastructure (transportation and communication systems, water-recycling systems, clean energy and electrical power lines, etc.) and industrial structure, such as changing the size of companies, from small to large as in Landskrona (Sweden) [78], when a critical mass is needed, or vice versa depending on local resources and infrastructure or the phasing-out of the heavy polluting enterprises and the introduction of light economic activities, such as high-tech industries, tourism, culture, and so on [43]. The importance of the construction and demolition sector should not be disregarded at the urban level, with options to recover and reuse concrete, iron, aluminium, glass, and copper, among other valuable materials [79].

In China more than one hundred eco-city projects have been developed [80]. Experience with European eco-cities can also be found in Germany, Sweden and the UK [81]. Beijing, Shanghai, Tianjin and Dalian have developed in recent years eco-cities pilot projects for the purpose of investigating the evolution of $\mathrm{CE}$ in terms of efficient resource use (e.g., energy intensity per GDP and water intensity per capita), municipal waste production, and waste treatment and reclamation (the rate of waste water treatment, rate of industrial solid waste reuse) [82]. The results show important progress from 2005 to 2010 in the four Chinese eco-cities mentioned, with the highest reductions observed in energy and water consumption indicators. The major drivers of performance improvement have been government intervention in the high pollutant and energy consuming industrial sectors, by means of heavy industry relocation, the introduction of regulations in polluting sectors and the highest availability of energy efficient technologies and equipment in the four ecocities, compared to other Chinese cities.
Ideally $\mathrm{CE}$ transition seems to imply the objective of reducing waste generation to zero [24]. Some cities, given their critical role in resource use [83], have established zero waste programmes [84]. One of these programs in Durban (South Africa), analysed by Matete and Trois [85], has the potential to closely approach zero waste implementation, even if full recycling is impossible for all types of materials (e.g., paper). Following the zero waste ideal, Zaman and Lehmann [86] tested a Zero Waste Index (quantification of the potential for virgin materials to be replaced by the waste management city system) to overcome the limits of the waste sorting rate (one of the most common indicators used by municipalities to measure the current performances of waste management systems), introducing aspects of waste prevention. The zero waste goal in cities is also included within the European Union policy, as indicated by the 7 th Environment Action Program, with the aim of virtually eliminating landfilling by 2020 [87], whereas the Landfill Directive, 1999/31/EC [88] only required EU Member States to reduce the landfilling of biodegradable municipal waste to less than $35 \%$ of the amount produced in 1995. Some EU Member States (Austria, Belgium, Denmark, Germany and Netherlands) have already achieved the targets indicated by the EU Landfill Directive. The use of different normative instruments (tax, bans, and regulations) has contributed to the low landfilling rates, particularly landfill taxes.

Three main typologies of matter and energy flows are involved at the urban/metropolitan area level:

- primary material and energy resources (construction materials, fuels, food, goods and commodities, water, focus on waste prevention, minimisation of input flows, non-renewable versus renewable aspects);

- flows from one to another production sector that are still useful (reuse, planning, transferring, exchanging);

- waste and residues from the production and consumption sectors (recycling and recovery, disposal).

The convergence of technical expertise, stakeholder awareness, adequate business models, political will, careful planning, and innovation capability are much needed, and may constitute the skeleton for the successful regeneration of very degraded areas and living conditions.

The implementation of an urban circular economy, the appropriate resource management, the shift to providing services instead of products (e.g., good mobility instead of cars), and the better image that such improvements provide, are likely to attract new companies and generate innovative businesses, thus generating a new set of jobs over the logistic chain, that replaces old, no longer sustainable jobs, while also decreasing environmental impacts. 


\subsection{Top-down and bottom-up integration. A Community-oriented circular economy}

All the primary production and consumption processes in agriculture, agro-industrial, commercial, household sectors (including waste management, reuse and recycling), produce a large amount of organic and inorganic waste and residues that create non-negligible environmental burdens, processing expenses, and social concerns. Disposal is never easy or cheap. In general, local managers and administrators are only aware of one or two options (landfilling, incineration), the implementation of which translates into conflicts, expenses, and the loss of valuable resources and opportunities. In order to reverse such an unsustainable situation, a network of compartments, actors, and innovative activities must be identified, developed and integrated, capable of processing each kind of substrate into some kind of useful product. Each stakeholder (individual, small or medium enterprise, municipal agencies) has the potential to become a valuable component of the network, to develop technology and innovation, to help generate added value products and to contribute to new jobs and income patterns. The network economy that can be created around the circular economy concept fulfils the European Union programmes and Directives for waste reduction, waste recycling, the greater use of renewable sources and the decrease of $\mathrm{CO}_{2}$ emissions. In particular, the concept fulfils the EU Directive 2009/28/CE of the European Parliament and of the Council of 23 April 2009 on the promotion of the use of energy from renewable sources (so-called 20-20-20 Directive).

The successful implementation of circular urban systems requires the above and other recovery processes be integrated into an organised whole. This preliminarily calls for the involvement of stakeholders in a "visioning" exercise. Without such involvement, there are few hopes of achieving results, and resource management conflicts may arise. In general, "people do not resist change, people resist being changed" (Peter Senge ${ }^{6}$ ).

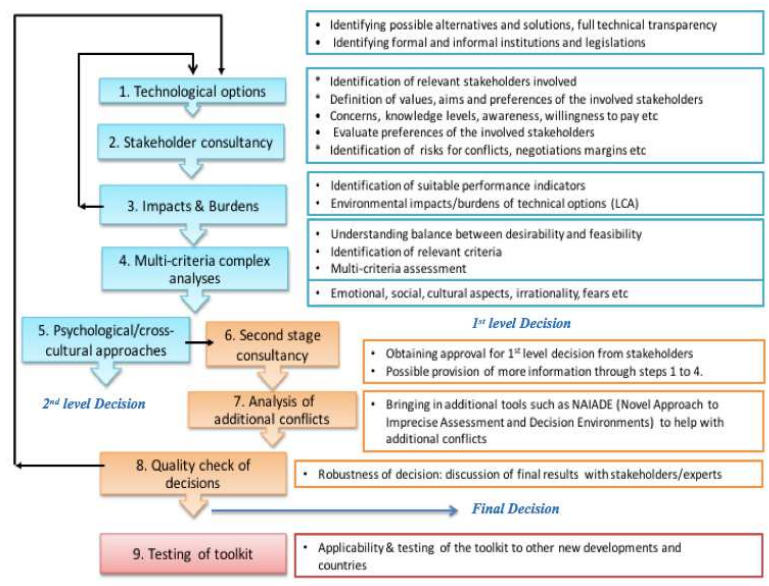

Fig. 4. Participatory Roadmap diagram (modified from Hornsby et al [19]).

\footnotetext{
${ }^{6}$ http://www.leadershipnow.com
}

The inclusion of stakeholders has two features:

a) stakeholders see things that administrators and scientists may not see, or disregard;

b) stakeholder involvement allows the search for optimised solutions (optimum compromise) towards the prevention of conflicts.

For this to happen, a roadmap for stakeholder consultancy and participatory processes, must be implemented, as designed in Figure 4.

\section{A circular mosaic of success stories and projects}

How likely is the transition to circular economy in different areas worldwide? Is it possible to identify success stories that show appropriate resource management through broad-minded planning ahead, and wise recycling after use? The results from a selection of investigated cases show that a mix of top-down and bottom-up policies is potentially able to decrease wasteful uses of resources by means of the appropriate recovery of downstream matter and energy flows, thus providing economic and environmental benefits. Technological solutions may not be a sufficient tool for a sustainable society, and much deeper lifestyle changes are instead required, however, increasing circular patterns and technologies, to be seen as the selforganising tesserae of a mosaic of innovative and participatory efforts, may allow sufficient transition time to promote the required global shift towards sustainable production and consumption patterns. In the following, we list and describe a number of investigated solutions, in order to show their potential contribution to appropriate resource uses.

\subsection{Urban mining}

Urban waste management has been and still is among the most controversial topics in resource use patterns. Many proposals have been put forward for collection and management, although the largest part of the more than 2 billion tons of waste annually generated worldwide is currently still disposed of in landfills or incinerators (even without energy generation). End-of-pipe solutions are unlikely to be very helpful, if they are not accompanied by prevention measures that promote upstream waste reduction and less wasteful lifestyles (e.g., no throw-away plastic tools, less plastic packaging and containers). Appropriate technologies can also become tesserae of the circular mosaic, however, at least until preventive measures are enforced. The EU LIFE MARSS (Material Advanced Recovery Sustainable Systems) project [89], of which the authors of this paper have been team members, addressed a technological way to safely treat the unsorted urban waste and recover their resource value, thus allowing a sufficient transition time towards radical waste reduction. In fact, in many countries worldwide, and in Europe as well, waste collection and management systems are still based on conventional methods, with more than $60 \%$ of urban garbage still unsorted and treated in landfills and old- 
fashioned mechanical biological treatment (MBT) plants. The separation of organic fraction and recyclable fractions (plastic, glass and paper) is often made difficult by reciprocal contamination due to inaccurate sorting. During the MARSS project (2012-2015) we therefore developed a technological module able to treat about 10 $\mathrm{t} / \mathrm{h}$, recover the fractions of ferrous and non-ferrous metals, and to separate the biogenic fractions of MSW (up to 50\%) and convert it into a biomass feedstock for renewable energy production in decentralised combined heat and power units. On-field measures, life cycle analyses, and an assessment of socio-economic impacts confirmed the environmental and social feasibility of the module as a transition solution in areas where advanced circular designs are not yet implemented. The implementation of the MARSS technology in a demonstration case study suggested significant benefits, including the reduction of harmful greenhouse gas (GHG) emissions, reduction of the amount of biological municipal waste going to landfill, the prevention of losses of valuable metals and other materials suitable for recycling, the local production of electricity and heat from household waste, and increasing renewable energy potential for urban communities, and the prevention of soil and ground water contamination from landfill sites $[19,20,90-92]$. While aware that burning organic matter is always a loss of potentially valuable resources, and something that should be prevented, the proposal stems from the fact that more than $50 \%$ of waste worldwide and in Europe is still landfilled or incinerated without any useful outcome, and gives rise to dangerous and uncontrolled emissions.

\subsection{Waste cooking oil}

Waste cooking oil (WCO) is a domestic waste generated from households and restaurants, as the result of using edible vegetable oil for cooking and frying. Its inappropriate disposal may generate heavy pollution in water bodies, while at the same time losing the resource value of a still usable material. WCO as a biodiesel feedstock has been identified as an alternative source of fatty materials for the production of biofuels [93]. Diverting WCO from improper disposal extends the product life cycle and helps prevent the contamination of ground and surface water. WCO is most commonly poured away in sanitary sinks and toilets, thus reaching and damaging sewer systems and requiring more expensive treatment to prevent pollution. The evaluation of costs and benefits was performed in collaboration with two local companies in the Campania Region (Papa Ecologia Srl, active at the regional level in the collection and treatment of waste cooking oil from restaurants and food industries; and PROTEG SpA, active in the treatment of the raw cooking oil to a purified oil). The purified oil (usable as fuel in industrial boilers) can also be converted to biodiesel and glycerine through transmethyl-esterification in a chemical plant (in our case, the DP Lubrificanti, Lazio Region, Italy). Results from the life cycle assessment (shown in Figure 5) indicate that recycled cooking oil generates a biodiesel that is characterised by a much lower environmental impact than biodiesel from dedicated oil crops and fossil diesel. Considering the large amounts of cooking oil used annually in Italy and worldwide, its recovery and conversion to usable resources has economic, social and environmental advantages.

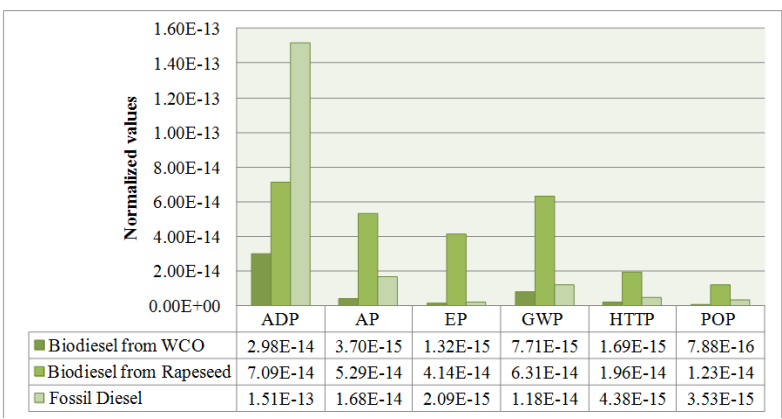

Fig. 5. Normalised LCA impacts of biodiesel from WCO, rapeseed and fossil diesel [93] (dimensionless units due to LCA normalisation). Acronyms: Abiotic Depletion Potential (ADP), Acidification Potential (AP), Eutrophication Potential (EP), Global Warming Potential (GWP), Human Toxicity Potential (HTP), Photochemical Oxidation Potential (POP).

\subsection{Recovery of waste electric and electronic equipment (WEEE)}

Waste of electrical and electronic equipment (WEEE) such as computers, televisions, refrigerators and mobile phones (not to speak of the extremely large number of smaller devices, e.g. switchers, light bulbs, etc.) is one of the fastest growing waste streams in the EU, with some 9 million tons generated in 2005, and expected to grow to more than 12 million tons by 2020 [94] Similarly, about 50 million tons of e-waste were generated worldwide in 2018, (WEEE Forum, 2019), 50\% of which was informatics equipment (computers, smartphones, TVs) and the remaining fraction larger household appliances.

Unfortunately, only $20 \%$ of global e-waste is recycled each year (WEEE Forum, 2019), translating into 40 million tons that is landfilled, burned or illegally traded or treated. There is no need to point out that such a situation generates a loss of valuable resources on one side, and on the other side huge damage to environmental and human health. The percentage of WEEE recycled in the EU is slightly higher, around the $35 \%$, in spite of legislation issued in the EU and several other countries worldwide for the appropriate collection and recovery of electric and electronic equipment.

Research developed in our team into end-of-life of informatics equipment and photovoltaic modules has shown the huge advantage of reusing and recycling. We developed the REBIT Project at Parthenope University, Napoli, with a special focus on the reuse of still usable informatics materials (after repair and regeneration) in junior schools and social centres [95], thus creating local computer laboratories for users characterised by less sophisticated informatics needs. The results about the recovery of informatics equipment [96] and photovoltaic equipment $[97,98]$ suggested the advantage of material recovery and related energy savings over the entire 
production and use chains of this equipment. For example, Figure 6 shows the material composition of a desktop computer.

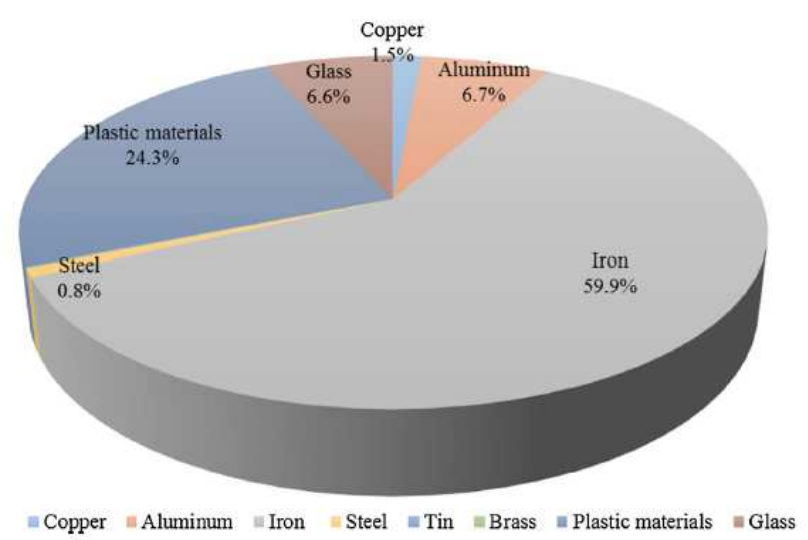

Fig. 6. Inventory of main primary materials within a desktop PC [96].

Based on such components, the $\mathrm{CO}_{2}$ emissions for the construction and five-year use of a desktop computer (mass equal to $14 \mathrm{~kg}$ ) from virgin materials and using non-renewable electricity were estimated as $516 \mathrm{~kg}$, whereas assuming the use of recycled materials and renewable electricity these emissions would decrease to $55 \mathrm{~kg} \mathrm{CO}_{2}$ [96]. For a laptop computer (mass between 2$3 \mathrm{~kg}$ ) the $\mathrm{CO}_{2}$ emissions would be $285 \mathrm{~kg}$ reduced to 40 $\mathrm{kg}$.

\subsection{Electricity from animal biomass residues}

Animal by-products from slaughterhouses are a special kind of waste that may have significant risks for human health, if not properly disposed of, due to its organic nature. They are defined by European Directive 2002/1774/EC as entire bodies, or parts of animals or products of animals, not intended for human consumption. We have investigated the use of animal fat from slaughter facilities and markets via the PROTEG SpA Company.

Among the options available (the conversion of edible parts into animal feed, conversion of non-edible fat into fuel for electricity production, conversion into biobased chemicals, mainly PHA, polyhydroxyalkanoates), the company runs a 5 MW electricity power plant fed by animal by-products from all over the Campania Region. At present, about 65,000 tons of animal residues are treated per year, yielding 15,600 tons of animal fat, of which 8,500 tons are converted to about $40 \mathrm{GWh} / \mathrm{yr}$ of electricity in a company managed $5 \mathrm{MW}$ cogeneration power plant. LCA results (shown in Figure 7) confirm that electricity from animal by-products has a much lower impact than electricity from fossil fuels in the Italian national grid $[99,100]$.

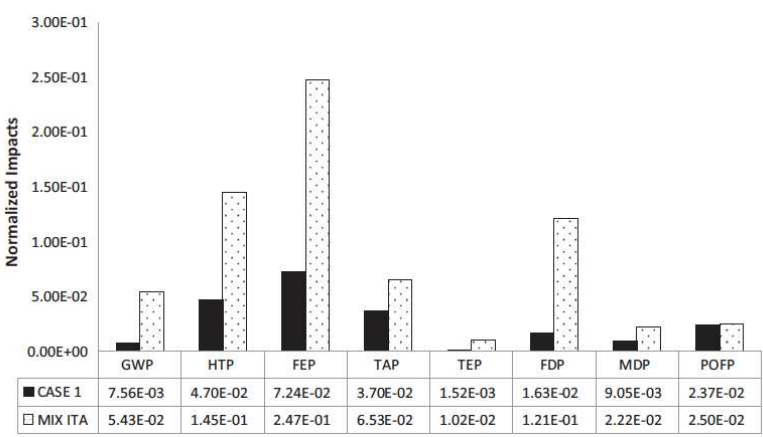

Fig. 7. ReCiPe Midpoint $\mathrm{H}$ normalised impacts for CASE 1 and MIX ITA electric production (dimensionless units due to normalisation procedure). CASE 1 refers to a zero-burden LCA evaluation for electricity from slaughterhouse waste; MIX ITA refers to Italian grid electricity production, for comparison) (Santagata et al., 2017). Acronyms: Global Warming Potential (GWP), Human Toxicity Potential (HTP), Fossil Depletion Potential (FDP), Metal Depletion Potential (MDP), Water Depletion Potential (WDP), Freshwater Eutrophication Potential (FEP), Terrestrial Acidification Potential (TAP), Terrestrial Ecotoxicity Potential (TEP), Photochemical Oxidant Formation Potential (POFP).

Other uses have also been investigated [101, 102], confirming the results presented in this paper, thus showing that circular patterns able to recover the resource value of residues and waste are rewarding and decrease environmental impacts. This is not, of course, a solution for other important aspects that could be raised (e.g., intensive livestock farming, excessive carnivore diets, population increase, etc.), which should also be urgently addressed, however, it can be considered at least one of the tesserae of the sustainability mosaic, towards more socially radical or more technologically advanced solutions.

\subsection{Fuels and chemicals from biomass waste and residues}

Biomass has been considered a potential substrate for biofuel production since the first signs of potential fossil fuels depletion. The apparently successful bio-alcohol program in Brazil in the 1980s, followed by bioethanol plans from corn in the USA and Europe were gradually replaced by increasing uncertainty about the real benefits in terms of the output/input energy ratio [103-106] leaving the stage free for other options, such as biofuels from oil seed crops and residual lignocellulosic waste and finally the more circular "biorefinery" concept, with the multiple production of chemicals and energy [107110].

In spite of the many efforts invested in theoretical and applied research, biofuel production has never shown sufficiently strong results in terms of yield per hectare and output/input energy ratio. Instead, the multioutput production of fuels and chemicals from biomass residues within a biorefinery framework - although not yet fully investigated and implemented - promises a much more interesting scenario for the replacement of fossil fuels as feedstock for chemical industry and energy production. From a technical point of view, a 
large fraction of industrial chemicals and materials from fossil resources can already be replaced by their biobased counterparts, and more is being done by biochemical companies, such as the Italian Novamont, among others. Fossil-based chemistry is still dominant in the market due to optimised production processes and lower oil costs. The best approach to maximise the valorisation of biomass is the processing of biological feedstock in integrated biorefineries where both biobased chemicals and energy carriers can be produced, similar to a traditional petroleum refinery. Figure 8 offers a potential integrated system of production and conversion activities at the regional scale, where the main products are sent directly to the market, while residues or marginal products are converted through biochemistry processes for energy, biochemicals and biopolymers.

\subsection{Urban wastewater circularity}

Urban wastewater collected through the sewage system towards treatment plants is at the same time a problem (presence of pollutant and toxic elements; excess of nutrients; presence of plastic materials) and a challenge (energy and matter recovery; extraction of fertilisers). Buonocore at al. [111] investigated bioenergy (electricity and heat) production in Enköping (Sweden) by applying the SUMMA (Sustainability Multimethod Multiscale Assessment) approach $[112,113]$ to the whole chain of wastewater and biomass residue recovery.

The system integrates wastewater treatment, willow farming, and a combined heat and power plant (CHP). The willow cropping system benefits the biological treatment of nutrient-rich municipal wastewater, leading to a substantial increase in biomass yield, the reduced use of chemical fertilisers, and the lower pollution of groundwater. The CHP plant cogenerates electricity sold to the Nord Pool market (including Sweden, Norway, Denmark, and Finland) and heat is delivered by district heating to almost all the buildings in the town of Enköping. A variety of other biomasses are used in the CHP plant, including conventionally farmed willow, residues from wood industries, agricultural waste, and forest residues, thus generating a loop of biobased energy production, industrial activities and environmental protection practices. The results of the study identified a large set of improvement options, output/input energy ratios in the range 9-11, and decreased emissions compared to business-as-usual alternatives.

A similar study was performed by Buonocore et al. [115] investigating the performance of a wastewater treatment plant in Nocera Inferiore (province of Salerno, Italy), serving 300,000 inhabitants (Figure 9). The results identified a large energy demand due to process electricity and large environmental impacts in the form of human ecotoxicity (due to sludge landfilling) and freshwater eutrophication (due to the high nitrogen content of discharged water, although within legal limits). The study identified interesting circular options, via biogas production from anaerobic digestion of sludge, digestate drying and gasification, the use of discharged water for energy crop fertirrigation, cogeneration of electricity and heat from biogas, syngas and energy crops, and finally thee extraction of platform chemicals from residual biomass through acid or enzymatic hydrolysis.

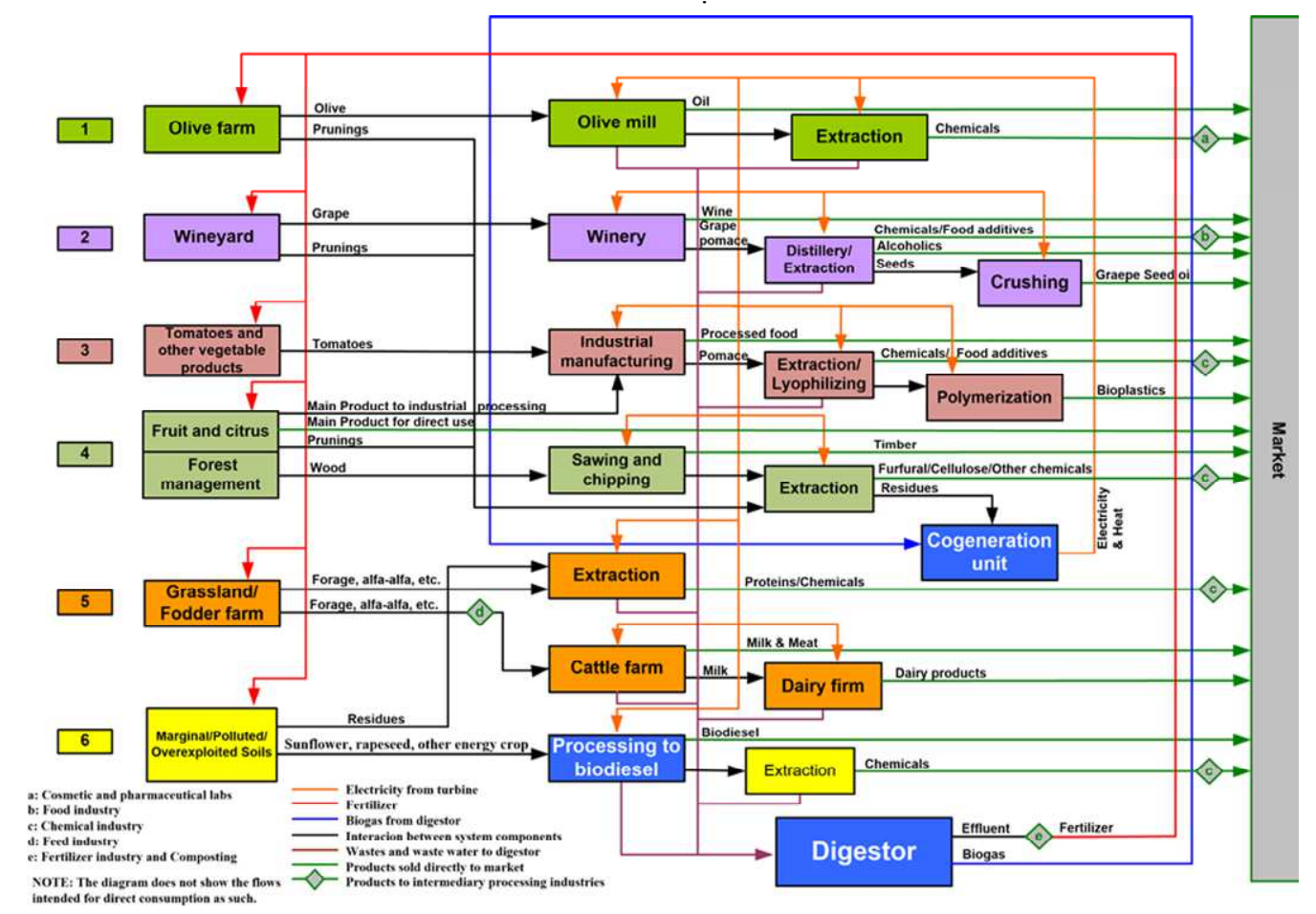

Fig. 8. An integrated system of agro-industrial production and conversion activities in support of a regional scale biorefinery system [114]. 


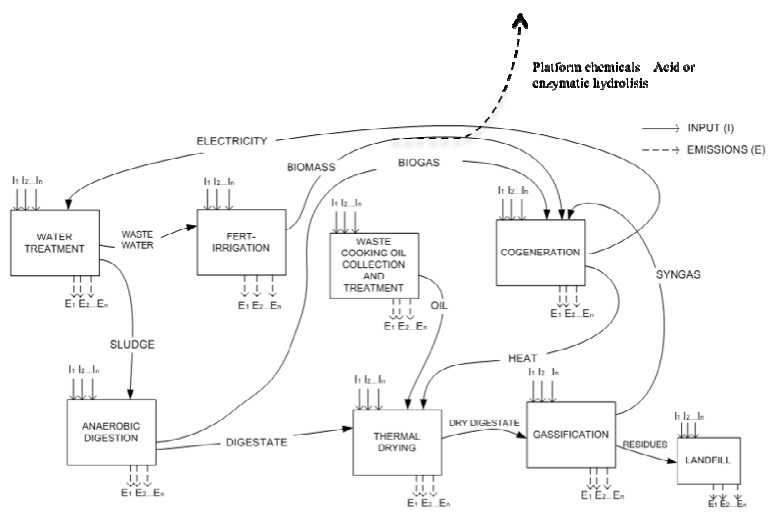

Fig. 9. Circularity patterns around waste water treatment (WWT) plant in Campania region [115]

\subsection{Construction and demolition waste}

As shown above for Italy, construction and demolition is among the sectors that generate the largest amount of abiotic waste in urban systems worldwide. The widespread urbanisation process that took place in the second half of the last century and is still ongoing, leading to the growth of megacities and abandonment of rural areas, generates as a side effect the need for new building, maintenance and refurbishment over a building's life time, and finally the demolition, disposal and recycling of end-of-life construction materials. The same is true for urban roads. As a consequence, disposal areas, transport processes and recovery/recycling facilities are needed, to also prevent additional mining and related landscape degradation.

Ghisellini et al. [48, 79] investigated the environmental and economic costs and benefits of a circular economy approach to construction and demolition materials, with special focus on the transition towards cleaner production in the construction and demolition sector of China. These authors identified the main barriers to the increased circularity of construction and demolition materials and a set of solutions proposed worldwide, summarised in Table 1, showing once again that a huge problem could be converted into a resource, from the "urban mining" perspective mentioned above, provided appropriate investments, planning and regulations.

\section{Innovative normative, economic and supporting tools}

A number of new policy measures should be considered: a more proactive use of public procurement, earmarking investments in favour of resource efficiency within the EU's different funding schemes, the adoption of resource efficiency targets for materials where scarcity is looming or the overall environmental impact of resource extraction and use is significant, and the promotion of new business models geared at functional sales. Table 1 shows barriers and potential solutions to circular economy patterns in the urban construction and demolition sector [48, 79].
Table 1. Circular economy patterns in the urban construction and demolition sector.

\begin{tabular}{|c|c|c|}
\hline Sector & $\begin{array}{l}\text { Description of } \\
\text { barriers }\end{array}$ & Potential solutions \\
\hline Economic & $\begin{array}{l}\text { High prices of } \\
\text { recycled } \\
\text { concrete } \\
\text { products and } \\
\text { lower } \\
\text { acceptance of } \\
\text { these products } \\
{[116]} \\
\text { High } \\
\text { availability and } \\
\text { low cost of } \\
\text { virgin raw } \\
\text { materials [117, } \\
118] \\
\end{array}$ & $\begin{array}{l}\text { Improve information } \\
\text { about the classification of } \\
\text { recycled products [116]. } \\
\text { Introduce taxes on the use } \\
\text { of primary raw materials } \\
\text { [119] coupled with an } \\
\text { increase in the landfill tax } \\
\text { [120]; } \\
\text { a reform of VAT to } \\
\text { exclude products made } \\
\text { with secondary materials } \\
\text { [119]. }\end{array}$ \\
\hline Political & $\begin{array}{l}\text { Ineffective } \\
\text { policies } \\
\text { guiding } \\
\text { C\&DWM: lack } \\
\text { of specific } \\
\text { regulations, } \\
\text { norms and } \\
\text { standards for } \\
\text { C\&DWM } \\
{[121] .}\end{array}$ & $\begin{array}{l}\text { Adoption of a political } \\
\text { system designed for } \\
\text { guiding and enforcing } \\
\text { C\&DWM (definition of } \\
\text { the operability and } \\
\text { responsibility of waste } \\
\text { activities in the supply } \\
\text { chain, including on-site } \\
\text { sorting, reuse, recycling, } \\
\text { and disposal of C\&DW) } \\
\text { [121]. }\end{array}$ \\
\hline Legislative & $\begin{array}{l}\text { The normative } \\
\text { system guiding } \\
\text { C\&DWM is } \\
\text { not suitable for } \\
\text { companies of } \\
\text { all sizes (costly } \\
\text { legal } \\
\text { framework) } \\
\text { [122]. }\end{array}$ & $\begin{array}{l}\text { Adoption of legislative } \\
\text { tools better suited for } \\
\text { companies of all sizes, } \\
\text { based on an ex-ante and } \\
\text { ex-post (feedback } \\
\text { mechanism) evaluation of } \\
\text { the proposed tools [ } 2] .\end{array}$ \\
\hline Informative & $\begin{array}{l}\text { Lack of } \\
\text { preference for } \\
\text { recycled } \\
\text { products by } \\
\text { designers } \\
\text { [124]; negative } \\
\text { perception of } \\
\text { clients towards } \\
\text { recycled } \\
\text { products. }\end{array}$ & $\begin{array}{l}\text { Development of } \\
\text { information about the } \\
\text { quality and functionality } \\
\text { of recycled products } \\
\text { [124]. } \\
\text { Adoption of a suitable } \\
\text { classification of recycled } \\
\text { products and certification } \\
\text { schemes, based on the } \\
\text { traceability of the } \\
\text { recycled products } \\
\text { throughout their life cycle } \\
\text { [118]. }\end{array}$ \\
\hline Managerial & $\begin{array}{l}\text { Ineffective } \\
\text { C\&DW } \\
\text { management } \\
\text { and continuous } \\
\text { increase of } \\
\text { C\&DW [125]. }\end{array}$ & $\begin{array}{l}\text { Focus on a preventive } \\
\text { approach and circular } \\
\text { design in construction } \\
\text { industry [125]; financial } \\
\text { viability of the adoption } \\
\text { of preventive solutions; } \\
\text { legislative support for the } \\
\text { design stage [125]. } \\
\text { Development of } \\
\text { knowledge on effective } \\
\text { waste management } \\
\text { options [125]; Analysis of } \\
\text { costs and benefits of } \\
\text { preventive measures in } \\
\text { design [125]. }\end{array}$ \\
\hline
\end{tabular}


A focus on funding schemes is necessary. In times of scarce public national or local resources and of economic turmoil worldwide, it is not easy to think that an innovative proposal with a high risk of failure can be funded and supported through conventional supporting tools (public money, banking loans and derivatives, private investors). Instead, new funding schemes must be explored, including local cooperative efforts, participatory and shared ownership, diversion of funding from big centralised treatment plants, crowdfunding.

After the first results achieved through innovative schemes become visible, conventional investors will probably reconsider their choices, on the basis of the economic profitability of the innovative solutions. A communication campaign about the transition while it is in progress might also be very helpful.

Rethinking taxation schemes could provide support for the CE. Moving away from taxes on labour or income to taxes on the wasteful use of resources might provide an incredible push towards circular economy patterns. Previous typologies of taxes on $\mathrm{CO}_{2}$ emissions or other kinds of emissions did not work due to their low rate of implementation, which did not encourage transition. If labour and income taxes were decreased by a large fraction, this would allow a parallel increase of taxation on the consumption of non-renewable resources in the form of materials and fossil fuels. Such a tax shift would accelerate the transition to a circular economy, which is low-carbon and resource-efficient in nature. Such taxation would be much more effective if it were able to address the content and the amount of recycled materials within a new product. Bimonte and Ulgiati [126] suggested an emergy ${ }^{7}$-based taxation scheme to replace at least a fraction of income and labour taxes and focus on the wasteful "disposable" use of resources, measured by means of the emergy (environmental cost) approach. Barnes [127] also suggested a shift from income taxation to natural capital protection-oriented models, through a system of "Common Trusts", a market-based legal entity with the power of limiting the use of scarce resources, charging rents and paying dividends based on wise use of resources.

Wijkman and Skånberg [14] proposed changes to the system of VAT - value added tax. According to these authors, goods produced from secondary materials - where VAT has already been paid once should be exempted from VAT. Such a reform would promote the use of secondary materials - reuse and recycling - and help correct a situation where it is often

\footnotetext{
7 The Emergy Accounting (spelled with an $\mathrm{m}$ ) is an assessment method of the environmental value of resources based on the time needed for their generation by the biosphere driving forces. It converts all the energy and material input flows that contributed to a resource generation over time into solar equivalent units, so that the total amount of Unit Emergy Values thus calculated provides a measure of the biosphere work invested. The higher this value, the higher the quality of a resource, in that its replacement would require a large space-time biosphere activity $[128,129]$.
}

less expensive to use virgin materials than recycled ones.

The definition of a new standard with which to certify the quality and environmental management of reuse (circular) operators is also crucial in order to promote new jobs within a circular framework (also to replace potential jobs losses in linear production processes). In a situation where reuse and recycling become more widespread activities, it is also important to have or acquire the expertise to identify the best reuse or recycling or conversion options, the necessary technology, and the potential advantages and costs. "Circular" operators have to be able to face the organisational (where and how), bureaucratic (certification, permits) and quality aspects of the recovery and exchange of material and energy flows. This requires the implementation of appropriate training by interested organisations (city administrations, accreditation bodies, industrial associations, environmental NGOs), in order for the advantages of material and energy recovery and a decrease in environmental load to be real, quantified and publicly recognised. The professional expertise needed or acquired must be recognised as a public benefit, and adequately supported.

The recently developed ACCREDIA certification "Remade in Italy", which guarantees the content of recycled material used by Italian companies in the realisation of their products, and the traceability of the production itself, might be considered an example of new certification schemes to be developed and applied to good circular economy practices at an urban level. The ISO 50001 Energy Management System and the ISO 26000 on the Social Responsibility of a Business Organisation are clear examples of target-oriented standards. A circular economy standard for companies and operators has yet to be developed and would be a very important addition to the normative body of zerowaste and eco-efficiency activities at local and regional levels.

\section{Conclusions}

It is no longer possible to disregard the importance of appropriate resource use, from many different points of view. Resource depletion (be it fossil fuels, strategic minerals, fresh water and fertile soil) exposes the world economy to huge risks of instability and collapse, and calls for urgent measures to recover resource value through preventive design and recycling. Excess resource depletion is pushing economies towards the exploitation of mineral and fossil reservoirs previously disregarded because they were less profitable. This is likely to affect environmentally protected areas which may become new mines, new landfills or new cropped areas to replace those already polluted. Implementing circular patterns of preventive design, recovery and recycling is not only urgent, but also possible. It is unlikely that top-down directives can solve the

\footnotetext{
${ }^{8}$ https://www.remadeinitaly.it/about-us
} 
problems, nor can we wait until the problems are solved by new technologies, if any. A mix of participatory strategies, interacting bottom-up and topdown actions, innovative technologies and locally creative projects could be the basis for a roadmap towards wellbeing through environmental care and appropriate resource use and sharing. We have shown in this paper that a circular mosaic of options and locally implemented projects, if adequately interacting and promoted by administrators, businesses and citizens, have the potential to address and gradually solve energy, material resources, water and environmental problems, towards increased wellbeing for humanity and nature.

The authors gratefully acknowledge support from the Italian Ministry of Foreign Affairs and International Cooperation (MAECI - No. PGR00767) within the framework of the High Relevance Sino-Italian bilateral project "Analysis of the metabolic process of urban agglomeration and the cooperative strategy of circular economy".

\section{References}

1. W. Haas, F. Krausmann, D. Wiedenhofer, M. Heinz, An Assessment of Material Flows, Waste Production, and Recycling in the European Union and the World in 2005, Journal of Industrial Ecology, 19, 765-777 (2015).

2. W. Stahel, The circular economy, Nature 531, 435-438 (2016).

3. J. Korhonen, A. Honkasalo, J. Seppälä, Circular Economy: The Concept and its Limitations, Ecological Economics, 143, 37-46 (2018).

4. UNEP, Global waste management outlook (2015) [Online].

Available: https://wedocs.unep.org/bitstream/handle/20.500.1 1822/9672/-Global_Waste_Management_Outlook2015Global_Waste_Management_Outlook.pdf.pdf ? sequence $=3 \&$ amp\%3BisAllowed $=$ [Access date: 27th April 2019].

5. W.P. Cunningham, M.A. Cunningham, B. Woodworth Saigo, Fondamenti di ecologia. McGraw-Hill, 360 pp. (2007)

6. L. Lebreton, A. Andrady, Future scenarios of global plastic waste generation and disposal, Palgrave Communications, 5 (2019).

7. Y. Geng, J. Sarkis, R. Bleischwitz, How to globalize the circular economy, Nature, 565, 153155 (2019).

8. P. Geddes, Cities in Evolution, Williams \& Norgate, London, pp. 265 (1915).

9. W. Stephen, Think Global, Act Local: The Life and Legacy of Patrick Geddes, Luath Press Limited, Edinburgh, pp. 140 (2015).

10. Drew, 2016

11. M.T. Brown, and S. Ulgiati, Understanding the global economic crisis: A biophysical perspective, Ecol. Modell, 223, 4-13 (2011).

12. M.T. Brown, and S. Ulgiati, The Tertiary Economy: A Threat to the Global Economy. In: Energy Security and Development. The Global
Context and Indian Perspectives. Edited by Sudhakara B. Reddy and Sergio Ulgiati. Springer, India, 307-319 (2015).

13. Ellen MacArthur Foundation, Towards the circular economy (2012) [Online]. Available: http://www.ellenmacarthurfoundation.org/business /reports [Access date: 10th September 2013].

14. A. Wijkman, K. Skånberg, The Circular Economy and Benefits for Society. An interim report by the Club of Rome with support from the MAVA Foundation and the Swedish Association of Recycling Industries [Online]. Available: www.clubofrome.org [Access date: 27th April 2019].

15. P. Ghisellini, C. Cialani, S. Ulgiati, A review on circular economy: The expected transition to a balanced interplay of environmental and economic systems. J Clean Prod, 114, 11-32 (2016).

16. W.W Clark II, Sustainable Communities. Springer Science+Business Media, New York, 314 pp. (2010)

17. G. Charonis, Degrowth, Steady state economics and the circular economy: three distinct yet increasingly converging alternative discourses to economic growth for achieving environmental sustainability and social equity, World Economic Association Sustainability Conference 2012 [Online]. Available: http://sustainabilityconference2012.worldeconomi csassociation.org/wpcontent/uploads/WEASustainabilityConference201 2_Charonis_Alternative-Discourses-to-EconomicGrowth.pdf [Access date: 19th October 2013].

18. V. Castellani, S. Sala, N. Mirabella, Beyond the throwaway society: a life cycle-based assessment of the environmental benefit of reuse. Integr. Environ. Assess. Manag. 11 (3), 373-382 (2015).

19. K. Hornsby, M. Ripa, C. Vassillo, S. Ulgiati, A roadmap towards integrated assessment and participatory strategies in support of decisionmaking processes. The case of urban waste management. J Clean Prod, 142, 157-172 (2017).

20. K. Hornsby, N. Head, E. Ploumistou, S. Ulgiati, Cross-Cultural Assessments and Stakeholder Consultancy towards Resource Waste Reduction and Climate Change Prevention. SOJ Symbiosis Online Journal - Psichology, 1-22 (2017).

21. G. Pauli, The Blue Economy: 10 years, 100 Innovations. 100 Million Jobs, Paradigm Publications, New Mexico, (2010).

22. G. Pauli, The Blue Economy [Online]. Available: https://www.gunterpauli.com/the-blueeconomy.html [Access date: 23rd August 2018].

23. D. Ness, Sustainable urban infrastructure in China: Towards a Factor 10 improvement in resource productivity through integrated infrastructure system. International Journal of Sustainable Development \& World Ecology, 15, 288-301(2008).

24. EC, European Commission, MEMO, Questions and answers on the Commission Communication "Towards a Circular Economy" and the Waste 
Targets Review (2014) [Online]. Available: http://europa.eu/rapid/press-release_MEMO-14450_en.htm [Access date: 11 July 2014].

25. EC, European Commission, Communication from the Commission to the European Parliament, The Council, The European Economic and Social Committee and the Committee of the Regions. Towards a circular economy: a zero waste programme for Europe, COM (2014) 398.

26. U. Mazzantini, Rivoluzione a Davos, il big business mondiale vuole l'economia circolare [Online]. Available: http://www.greenreport.it/news/consumi/rivoluzio ne-a-davos-il-big-business-mondiale-vuoleleconomia-circolare [Access date: 10 February 2014].

27. J.J. Park, M. Chertow, Establishing and testing the "reuse potential" indicator for managing wastes as resources. J. Environ. Account. Manage, 137, 45-53 (2014).

28. Y. Geng, J. Fu, J. Sarkis, B. Xue, Towards a circular economy indicator system in China: an evaluation and critical analysis. J Clean Prod, 23, 216-224 (2012).

29. UNEP, The Japanese Industrial Waste Experience: Lessons for rapidly industrializing countries (2013) [Online]. Available: http://www.unep.org/ietc/Portals/136/Publications/ Waste\%20Management/UNEP\%20DTIE_Japanes e\%20waste_english_web.pdf [Access date: 5 May 2015].

30. D. Whaugray, Davos 2013: circular economy offers opportunities for Latin America, The Guardian [Online]. Available: http://www.theguardian.com/sustainablebusiness/davos-2013-circular-economyopportunities-latin-america [Access date: 24 August 2013].

31. C. Stiehl, T. Hirth, Vom additiven Umweltschutz zur nachhaltigen Produktion. Chemie Ingenieur Technik 84, 963-968 (2012).

32. Z. Yuan, J. Bi, Y. Moriguichi, The Circular Economy; A New Development Strategy in China. Journal of Industrial Ecology 10, 4-8 (2006).

33. N.U. Yap, Towards a circular economy: progress and challenges. Green Management International 50, 11-24 (2005).

34. M.S. Andersen, An introductory note on the environmental economics of the circular economy. Sustainability Science 2, 133-140 (2007).

35. F. Zhijun, Y. Nailing, Putting a circular economy into practice in China. Sustainable Science 2, 95101 (2007).

36. F. Preston, 2012. A Global Redesign? Shaping the Circular Economy. Briefing Paper. [Online]. Available:

http://www.chathamhouse.org/sites/default/files/pu blic/Research/Energy,\%20Environment\%20and\% 20Development/bp0312_preston.pdf [Access date: 22 August 2013].

37. J. Naustdalslid, J. Circular economy in China - the environmental dimension of the harmonious society. International Journal of Sustainable Development \& World Ecology, 21:4, 303-313 (2014).

38. S. Prendeville, C. Sanders, J. Sherry, F. Costa, Circular Economy: is it enough? [Online]. Available:

http://www.edcw.org/sites/default/files/resources/ Circular\%20Ecomomy$\% 20$ Is\%20it\%20enough.pdf [Access date: 10 luly 2014].

39. CCICED, Circular Economy Promotion Law of the People's Republic of China [Online]. Available:

http://www.bjreview.com.cn/document/txt/200812/04/content_168428.htm [Access date: 27 April 2019].

40. Y. Geng, J. Sarkis, S. Ulgiati, Sustainability, wellbeing, and the circular economy in China and worldwide. Science, special issue "Pushing the Boundaries of Scientific Research: 120 Years of Addressing Global Issues", pp. 73-76 (2016).

41. Y. Fang, P.R. Coté, Q. Rong, Industrial sustainability in China: Practice and prospects for eco-industrial development. J. Environ.Account. Manage. 83, 315-328 (2007).

42. U. Mazzantini, La Cina divora materie prime: secondo l'ONU è il più grande consumatore mondiale [Online]. Available: http://www.greenreport.it/news/consumi/la-cinadivora-materie-prime-secondo-lonu-e-il-piugrande-consumatore-mondiale [Access date: 24 September 2013].

43. B. Su, A. Heshmati, Y. Geng, X. Yu, A review of the circular economy in China: moving from rethoric to implementation. J Clean Prod, 42, 215277 (2013).

44. UNEP, Resource efficiency: Economics and Outlook for China [Online]. Available: http://www.unep.org/pdf/China_Resource_Efficie ncy_in_English_2013.pdf [Access date: 24 September 2013].

45. Y. Geng, B. Doberstein, Developing the circular economy in China: challenges and opportunities for achieving "leapfrog development". International Journal of Sustainable Development and World Ecology 15, 231-239 (2008).

46. J.A. Mathews, H. Tan, Progress towards a circular economy: the drivers and inhibitors of Eco-industrial initiative. Journal of Industrial Ecology 15, 435- 457 (2011).

47. Europesworld, The circular economy is the basis of a new industrial policy [2014) [Online]. Available: http://europesworld.org/2014/06/15/thecircular-economy-is-the-basis-of-a-new-euindustrial-policy/\#.VQCon5VARdg [Access date: 11 March 2015]-.

48. Ghisellini, P., Ripa, M., Ulgiati, S., Exploring environmental and economic costs and benefits of a circular economy approach to construction and demolition materials. J Clean Prod, 178, 618-643 (2018) 
49. EU, Circular Economy [Online]. Available: http://ec.europa.eu/environment/circulareconomy/index_en.htm [Access date: 10 October 2018].

50. EU, Towards a circular economy [Online]. Available :

https://ec.europa.eu/commission/priorities/jobsgrowth-and-investment/towards-circulareconomy_en [Access date: 10 October 2018].

51. The World Bank, From What a Waste 2.0: A Global Snapshot of Solid Waste Management to 2050 [Online]. Available: http://pubdocs.worldbank.org/en/42985155293959 6362/What-a-Waste-2-Revised-version.pdf [Access date: 27 April 2019].

52. UNEP, United Nations Environment Programme (2015) [Online]. Available: https://www.unenvironment.org/resources/report/g lobal-waste-management-outlook. [Access date: 24/07/2019].

53. H. Park, Municipal Solid Waste Incineration in Japan, Submitted as coursework for PH240, Stanford University, Fall 2018 [Online]. Available: http://large.stanford.edu/courses/2018/ph240/parkh2/ [Access date: 27 April 2019].

54. Ministry of the Environment of Japan, Solid Waste Management and Recycling Technology of Japan. Toward a Sustainable Society [Online]. Available: http://large.stanford.edu/courses/2018/ph240/parkh2/docs/env-jp-2012.pdf [Access date: 27 April 2019].

55. I. Bello, M.N.B. Ismail, N. Kabbashi, Solid Waste Management in Africa: A Review. International Journal Waste Resources 6, 1-4 (2016).

56. J.E.M. Oteng-Ababio, O. Arguello, Gabbay, Solid waste management in African cities: Sorting the facts from the fads in Accra, Ghana. Habitat International 39, 96-104 (2013).

57. M.M. Mian, X. Zeng, A.A.N.B. Nasry, S.M.Z.F. Al-Hamadani, Municipal solid waste management in China: a comparative analysis. Journal of Material Cycles and Waste Management 19(3) (2016).

58. S. K. Ghosh, B. Debnath, R. Baidya, D. De, J. Li, S. Kumar Ghosh, L. Zheng, Kumar Awasthi, M. A. Liubarskaia, J. S. Ogola, A. N. Tavares, Waste electric and electronic equipment management and Basel Convention compliance in Brazil, Russia, India, China and South Africa (BRICS) nations. Waste Management \& Research 34, 8, 693-707 (2016).

59. UNEP, Waste management in ASEAN countries, report (2017) [Online]. Available: http://www.rrcap.ait.asia/Publications/Waste\%20 Management\%20in\%20ASEAN\%20Countries\%2 0Summary\%20Report.pdf [Access date: 27 April 2019

60. Eurostat, Glossary: Municipal waste [Online]. Available: https://ec.europa.eu/eurostat/statisticsexplained/index.php?title=Glossary:Municipal_wa ste [Access date: 27 April 2019].
61. Eurostat, Municipal waste by waste management operations (2017) [Online]. Available: http://appsso.eurostat.ec.europa.eu/nui/show.do?da taset=env_wasmun\&lang=en [Access date: 28 April 2019].

62. Eurostat, Municipal waste statistics (2019) [Online]. Available: https://ec.europa.eu/eurostat/statisticsexplained/index.php/Municipal_waste_statistics\# Municipal_waste_generation [Access date: 24 July 2019].

63. Eurostat, Municipal waste landfilled, incinerated, recycled and composted in the EU-28, 1995 to 2017 [Online]. Available: https://ec.europa.eu/eurostat/statisticsexplained/images/1/11/Municipal waste landfille $\mathrm{d} \% 2 \mathrm{C}$ incinerated $\% 2 \mathrm{C}$ recycled and composted in the EU-28\%2C 1995 to 2017.png [Access date: 28 April 2019].

64. European Commission, Circular Economy; Implementation of the Circular Economy Action Plan (2019) [Online]. Available: http://ec.europa.eu/environment/circulareconomy/index_en.htm. [Access date: 27 April 2019].

65. European Commission, Waste (2019) [Online]. Available:

http://ec.europa.eu/environment/waste/index.htm [Access date: 28 April 2019].

66. ISPRA, Municipal Waster Report (2018) [Online]. Available:

http://www.isprambiente.gov.it/en/publications/rep orts/municipal-waste-report-2018 [Access date: 28 April 2019].

67. EPA, Environmental Protection Agency July 2018 [Online]. Available: https://www.epa.gov/sites/production/files/201807/documents/2015_smm_msw_factsheet_072420 18_fnl_508_002.pdf [Access date: 25 July 2019].

68. J.P.A. Hettiaratchi, New trends in waste management: North American perspective. Proceedings of the International Conference on Sustainable Solid Waste Management, 5-7 September 2007, Chennai, India, pp. 9-14. (2007).

69. H. Hettiarachchi, S. Ryu, S. Caucci, R. Silva, Municipal solid waste management in Latin America and the Caribbean: Issues and potential solutions from the governance perspective. Recycling 3, 19, 1-15(2018).

70. K. Drew, Zero Waste: How does San Francisco do it? and, What's next?, Presentation given at the Environmental Forum of Marin, San Rafael, March 2013 [Online]. Available: http://www.coopcentabc.org.br/documentos/incine racao/Zero_Waste_San_Francisco_EUA.pdf [Access date: 28 April 2019].

71. L. Evans, Lessons from Kalundborg. Bus Environ, 6(1), 51(1995).

72. J. Ehrenfeld, N. Gertler, Industrial ecology in practice: the evolution of interdependence at Kalundborg. J Ind Ecol;1(1), 67-79 (1997). 
73. Ellen MacArthur Foundation, The circular model brief history and school of thought [Online]. Available:

http://www.ellenmacarthurfoundation.org/circulareconomy/circular-economy/the-circular-modelbrief-history-and-schools-of-thought [Access date: 10 October 2013].

74. EU, Circular Economy Package (2018) [Online]. Available: https://ec.europa.eu/info/eu-regionaland-urban-development/topics/cities-and-urbandevelopment/priority-themes/circular-economycities_en [Access date: 27 April 2019].

75. WEF, Circular Economy in Cities: Evolving the model for a sustainable urban future (2018) [Online]. Available: https://www.weforum.org/whitepapers/circulareconomy-in-cities-evolving-the-model-for-asustainable-urban-future [Access date: 27 April 2019].

76. H. Schnitzer, S. Ulgiati, Less bad is not good enough. J Clean Prod, 15, 1185-1189 (2007).

77. H. Schnitzer, S. Ulgiati, Special Issue on "Zero Emission Techniques and Strategies". J Clean Prod, 15, 209 (2007).

78. M. Mirata, T. Emtairah, Industrial symbiosis networks and the contribution to environmental innovation: The case of the Landskrona industrial symbiosis programme. J Clean Prod, 13, 9931002(2005).

79. P. Ghisellini, X. Ji, G.Y. Liu, S. Ulgiati, Evaluating the transition towards cleaner production in the construction and demolition sector of China: A review. J Clean Prod, 195, 418434 (2018)

80. A. Marion, Chinese eco-cities: The implementation of a new economic model? [Online]. Available: http://ecocitynotes.com/2012/06/chinese-ecocities-new-economic-model [Access date: 15 October 2013].

81. EU-ASIA, Eco-cities. Sharing European and Asian Best Practices and Experiences (2014) [Online]. Available: http://www.euasia.eu/publications/eco-cities [Access date: 19 March 2015].

82. Y. Geng, Q. Zhu, B. Doberstein, T. Fujita, Implementing China's circular economy concept at regional level: a review of progress in Dalian, China. Waste Management, 29, 996-1002 (2009).

83. Ramsar, The Ramsar Convention on Wetlands. Background and Context to the Development of Principles and Guidance for the Planning and Management of Urban and Peri-urban Wetlands (COP11 DR11) [Online]. Available:

https://www.ramsar.org/sites/default/files/docume nts/pdf/cop11/doc/cop11-doc23-e-urban.pdf [Access date: 13 August 2014].

84. Zerowaste Europe, Closing the loop of materials, Phasing out Toxics \& Emissions. Our Network (2014) [Online]. Available: http://www.zerowasteeurope.eu/zw-groups-ineurope [Access date: 22 July 2015].

85. N. Matete, C. Trois, Towards Zero Waste in emerging countries - A South African experience. Waste Management 28, 1480-1492 (2008).

86. A.U. Zaman, S. Lehmann, The zero waste index: a performance measurement tool for waste management systems in a "zero waste city". J Clean Prod, 50, 123-132 (2013).

87. EU, Official Journal of EU, L 354/171 Decision No 1386/2013/EU of the European Parliament and of The Council of 20 november 2013 on a General Union Environment Programme to 2020 "Living well within the limits of our Planet" [Online]. Available: $\quad$ http://eur-lex.europa.eu/legalcontent/EN/TXT/PDF/?uri=CELEX:32013D1386 \&from $=\mathrm{EN}$ [Access date: 23 August 2014].

88. EC, Council Directive 1999/31/EC of 26 April 1999 on the landfill of waste. Official Journal of the European Communities, L182/1 (1999).

89. MARSS, Material Advanced Recovery Sustainable Systems (2015) [Online]. Available: http://www.marss.rwthaachen.de/cms/front content.php?idcat=1\&lang $=2$ \&changelang=2 [Access date : 30 April 2019].

90. G. Fiorentino, M. Ripa, G. Protano, C. Hornsby, S. Ulgiati, Life Cycle Assessment of Mixed Municipal Solid Waste: Multi-input versus multi-output perspective. Waste Management, 46, 599-611. (2015)

91. M. Ripa, G. Fiorentino, H. Giani, A. Clausen, S. Ulgiati, Refuse recovered biomass fuel from municipal solid waste. A life cycle assessment. Applied Energy, 186(2), 211-225 (2017).

92. M. Ripa, G. Fiorentino, V. Vacca, S. Ulgiati, The relevance of site-specific data in Life Cycle Assessment (LCA). The case of the municipal solid waste management in the metropolitan city of Naples (Italy), J Clean Prod, 142, 445-460 (2017).

93. M. Ripa, C. Buonaurio, S. Mellino, G. Fiorentino, S. Ulgiati, Recycling Waste Cooking Oil into Biodiesel: A Life Cycle Assessment. International Journal of Performability Engineering 10 (4): 347356 (2014).

94. EU, Waste electrical \& electronic equipment (WEEE) [Online]. Available: http://ec.europa.eu/environment/waste/weee/index en.htm [Access date: 24 July 2019].

95. RE-BIT, Decolla il progetto RE-BIT [Online]. Available:

http://www.scienzeetecnologie.uniparthenope.it/R EBIT-2015.html [Access date: 30 September 2015].

96. A. Puca, M. Carrano, G. Liu, D. Musella, M. Ripa, S. Viglia, S. Ulgiati, Energy and eMergy assessment of the production and operation of a personal computer, Resour Conserv Recycl 116, 124-136 (2017).

97. F. Corcelli, M. Ripa, E. Leccisi, V. Cigolotti, V. Fiandra, G. Graditi, L. Sannino, M. Tammaro, S. Ulgiati, Sustainable urban electricity supply chain - Indicators of material recovery and energy 
savings from crystalline silicon photovoltaic panels end-of-life. Ecol. Indic., 94, 37-51(2018).

98. F. Corcelli, M. Ripa, S. Ulgiati, Efficiency and sustainability indicators for papermaking from virgin pulp. An emergy-based case study. Resour Conserv Recycl, 131, 313-328 (2018).

99. R. Santagata, M. Ripa, S. Ulgiati, An environmental assessment of electricity production from slaughterhouse residues. Linking urban, industrial and waste management systems. Applied Energy, 186, 175-188 (2017).

100.R. Santagata, S. Viglia, G. Fiorentino, G.Y. Liu, M. Ripa, Power generation from slaughterhouse waste materials. An emergy accounting assessment. J Clean Prod, 223, 536-552(2019).

101.K. Jayathilakan, K. Sultana, K. Radhakrishna, A.S. Bawa, Utilization of byproducts and waste materials from meat, poultry and fish processing industries: a review. J Food Sci Technol 49, 27893(2012).

102.K.H. Kettl, K. Shahzad, M. Eder, M. Narodoslawsky, Ecological footprint comparison of biobased PHA production from animal residues. Chem Eng Trans 29, 439-44 (2012).

103.M. Giampietro, S. Ulgiati, D. Pimentel, Feasibility of large-scale biofuel production. Does an enlargement of scale change the picture? BioScience, 47(9), 587-600 (1997).

104.M. Giampietro, S. Ulgiati, Integrated assessment of large scale biofuel production. Critical Reviews in Plant Sciences, 24, 365-384 (2005).

105.D. Pimentel, Biofuels, Solar and Wind as Renewable Energy Systems. Springer Science + Business Media B.V. (2008).

106.S. Fahd, S. Mellino, S. Ulgiati, Energy Cropping in Marginal Land: Viable Option or Fairie Tale? In: D. Pimentel (Editor), Global Economic and Environmental Aspects of Biofuels, Taylor \& Francis Group Publisher. Chapter 3. Pp. 51-96. (2012).

107.F. Cherubini, S. Ulgiati, Crop residues as raw materials for biorefinery systems - A LCA case study. Applied Energy, 87(1), 47-57 (2010).

108.G. Fiorentino, M. Ripa, S. Mellino, S. Fahd, S. Ulgiati, Life cycle assessment of Brassica carinata biomass conversion to bioenergy and platform chemicals. J Clean Prod, 66, 174-187 (2014).

109.G. Fiorentino, M. Ripa, S. Ulgiati, Chemicals from Biomass: Technological versus Environmental Feasibility. A Review. Biofuels Bioprod Biorefining 11, 195-214 (2017).

110.G. Fiorentino, A. Zucaro, S. Ulgiati, Towards an energy efficient chemistry. Switching from fossil to bio-based products in a life cycle perspective. Energy, 170, 720-729 (2019).

111.E. Buonocore, P.P. Franzese, S. Ulgiati, Assessing the environmental performance and sustainability of bioenergy production in Sweden: A life cycle assessment perspective. Energy, 37, 69-78 (2012).

112.S. Ulgiati, M. Raugei, S. Bargigli, Overcoming the inadequacy of single-criterion approaches to life cycle assessment. Ecol. Modell, 190, 432-42 (2006).

113.S. Ulgiati, M. Ascione, S. Bargigli, F. Cherubini, P.P. Franzese, M. Raugei, S. Viglia, A. Zucaro, Material, Energy and Environmental Performance of Technological and Social Systems under a Life Cycle Assessment Perspective. Ecol. Modell, 222 (1): 176-189 (2011).

114.A. Zucaro, G. Fiorentino S. Ulgiati, Constraints, impacts and benefits of lignocellulose conversion pathways to liquid biofuels and bio-chemicals. In: Yousuf A., Sannino F., Pirozzi D. (eds) Lignocellulosic Biomass to Liquid Biofuels, 1st Edition. Elsevier. Academic Press. In press. (ISBN: 9780128159361).

115.E. Buonocore, S. Mellino, G. De Angelis, G. Liu, S. Ulgiati, Life cycle assessment indicators of urban wastewater and sewage sludge treatment. Ecological Indicators, 94, 13-23 (2018).

116.V.W.Y. Tam, Comparing the implementation of concrete recycling in the Australian and Japanese construction industries. J Clean Prod, 17, 688-702 (2009).

117.H. Dahlbo, J. Bacher, K. Lahtinen, T. Jouttijarvi, P. Suoheimo, T. Mattila, S. Sironen, T. Myllymaa, K. Saramaki, Construction and demolition waste management and a holistic evaluation of environmental performance. J Clean Prod 107, 333-341 (2015).

118.R.V. Silva, J. De Brito, R.K. Dhir, Availability and processing of recycled aggregates within the construction and demolition supply chain: a review. J Clean Prod, 143, 598-614 (2017).

119.A. Wijkman, K. Skånberg, Club of Rome, The Circular Economy and Benefits for Society: Swedish Case Study Shows Jobs and Climate as Clear Winners. An Interim Report by the Club of Rome with Support from the MAVA Foundation and the Swedish Association of Recycling Industries (2015).

120.N. Toŝić, S. Marinković, T. Daŝić, M. Stanić, Multicriteria optimization of natural and recycled aggregate concrete for structural use. J Clean Prod, 87, 766-776 (2015).

121.W. Lu, H. Yuan, Exploring critical success factors for M.waste management in construction projects of China. Resour. Conserv. Recycl. 55, 201-208 (2010).

122.M. Gangolells, M. Casals, N. Forcada, M. Macarulla, Analysis of the implementation of effective waste management practices in construction projects and sites. Resour Conserv Recycl. 93, 99-111 (2014).

123.A. Jurgilevich, T. Birge, J. Kentala-Lehtonen, K. Korhonen-Kurki, J. Pietikäinen, L. Saikku, H. Schösler, Transition towards Circular Economy in the Food System. Sustainability, 8 (69), 1-14 (2015).

124.L.O. Oydele, S.O. Ajayi, K.O. Kadiri, Use of recycled products in UK construction industry: an empirical investigation into critical impediments 
and strategies for improvement, Resour Conserv Recycl. 93, 23-31(2014).

125.S.O. Ajayi, O.O. Lukumon, M. Bilal, O.O. Akinade, H.A. Alaka, H.A. Owolabi, K.O. Kadiri, Waste effectiveness of the construction industry: understanding the impediments and requisites for improvements. Resour Conserv Recycl. 102, 101$112(2015)$.

126.S. Bimonte S. Ulgiati, Economic Institutions and Environmental Policy, Ashgate, Aldershot, UK, 177-200 (2002).

127.P. Barnes, Capitalism 3.0-A guide to Reclaiming the CommonsBerret-Koehler Publishers, San Francisco, USA (2006).

128.H.T. Odum. Environmental Accounting Emergy and Environmental DecisionMaking. John Wiley \& Sons, Inc. (1996).

129.Brown, M.T., Ulgiati, S., Emergy analysis and environmental accounting. In: Cleveland, C. (Ed.), Encyclopedia of Energy. Academic Press, Elsevier, Oxford, UK, pp. 329-354 (2004). 